\section{Neurocutaneous Melanosis Associated with Prenatally Diagnosed Arachnoid Cyst}

Malformations of the central nervous system (CNS) are among the most common congenital anomalies. The development of diagnostic ultrasound imaging has resulted in significant advances in fetal neurosonography in particular. Depending on the imaging technology, the time at which examination is performed, and the experience of the examiner, a very precise differential diagnostic assessment of fetal brain structures can be performed and the large majority of CNS anomalies can be correctly diagnosed [1]. In some cases and also in regard to the interdisciplinary counseling of pregnant women together with neuropediatrics, intrauterine magnetic resonance imaging (MRI) can serve as a supplementary method to diagnostic ultrasound imaging. Additional CNS anomalies can be detected on MRI in select cases [2-4]. Arachnoid cysts are known CNS anomalies that can be accurately evaluated on ultrasound and generally have a good prognosis when their occurrence is isolated [5].

In contrast, neurocutaneous melanosis (NCM) is a very rare congenital disease with an estimated prevalence of 1:20,000$1: 200,000[6,7]$. The typical features of this disease are very large intradermal nevi or numerous intradermal nevi of varying size and benign or malignant melanocytic infiltrates with involvement of the leptomeninges [8]. Skin lesions are always already present at birth and are most commonly located in the lower trunk region, the gluteal region (64\%), and on the shoulders, head or extremities (32\%) [9]. Additional smaller foci can appear in the first year of life. The lesions extend into the subcutaneous tissue and the surrounding nerves and vessels. Malformations including Dandy-Walker complex, arachnoid cysts, and spina bifida occulta are described as additional anomalies in rare cases of NCM [10]. Patients with NCM can be asympto-

\section{Neurocutane Melanose assoziiert mit präntal diagnostizierte Arachnoidalcyste}

Fehlbildungen des zentralen Nervensystems(ZNS) gehören zu den häufigen angeborenen Anomalien. Betrachtet man die Entwicklung der sonografischen Diagnostik, zeigt sich, dass insbesondere die fetale Neurosonografie sehr grosse Fortschritte aufweist. Abhängig von der Gerätetechnik, vom Zeitpunkt der Untersuchung und der Erfahrung der Untersucher kann eine sehr präzise differentialdiagnostische Beurteilung der fetalen Hirnstrukturen durchgeführt und die überwiegende Mehrheit der ZNS-Anomalien korrekt diagnostiziert werden [1]. In einigen Fällen und auch im Hinblick auf die interdisziplinäre Beratung der Schwangeren gemeinsam mit der Neuropädiatrie, kann die intrauterine Magnetresonanztumografie (MRT) die sonografische Diagnostik ergänzen. Hierbei können in ausgewählten Fällen im MRT zusätzliche ZNS Anomalien erkannt werden [2-4]. Die Arachnoidalzysten gehören zu den bekannten ZNS- Anomalien, die bereits sonografisch exakt beurteilt werden können und eine i. R. insgesamt guten Prognose haben, wenn sie isoliert auftreten [5].

Die Neurocutane Melanose (NCM) ist dagegen eine sehr seltene angeborene Erkrankung mit einer geschätzten Prävalenz 1:20.000-1:200.000 [6, 7]. Typische Merkmale dieses Krankheitsbildes sind sehr grosse oder zahlreiche unterschiedlich grosse intradermale Nävi sowie benigne oder maligne melanocytäre Infiltrate mit Beteiligung der Leptomeningen [8]. Die Hautläsionen sind immer bei Geburt bereits vorhanden mit Lokalisation am häufigsten im unteren Rumpfbereich, der Glutealregion (64\%) und der Schultern, Kopf oder Extremitäten (32\%) [9]. Im ersten Lebensjahr können noch kleinere Herde neu auftreten. Histopathologisch weisen die Läsionen eine Tiefenausbreitung bis in die Subcutis und die umgebenden Nerven sowie Gefässe auf. Als weitere zusätzliche Anomalien sind bei der NCM in sel-

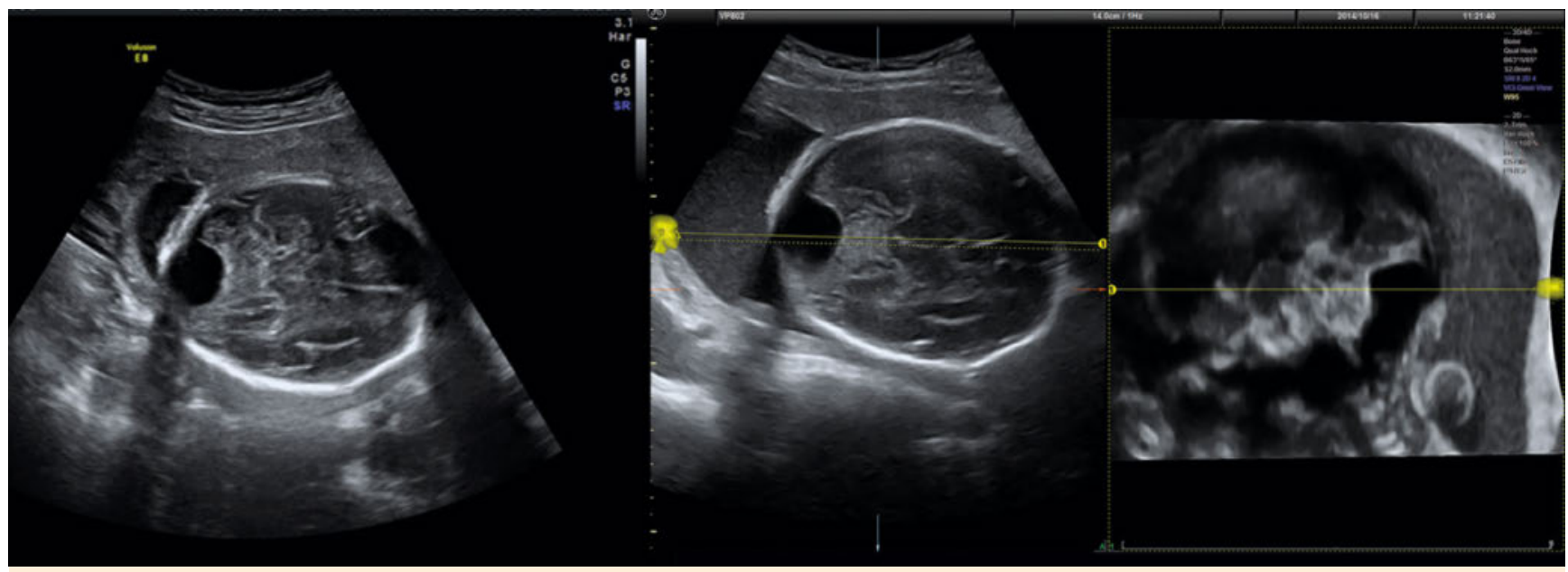

Abb. 1 Sonografische Diagnose einer fetalen Arachnoidalcyste.

Fig. 1 Sonographic diagnosis of a fetal arachnoid cyst 
matic or symptomatic regardless of the absence or presence of characteristic CNS findings on MRI. Approx. one third of patients with NCM are symptomatic [9]. Clinical symptoms typically occur in the first 2 years of life. CNS symptoms can be considered a result of infiltration of the leptomeninges, melanomas, intracerebellar and subarachnoid hemorrhage, or cervical or lumbosacral infiltration of the spinal cord. In addition, there is an increased risk of epilepsy, hydrocephaly, and ataxia. Neuromotor retardation can be expected in approximately $10 \%$ of cases [9]. Spinal melanosis is seen in approximately $20 \%$ of affected children. The spectrum of symptoms ranges from bladder and bowel incontinence to hemiparesis [9]. Primarily psychiatric disorders, such as depression and psychoses, at an age between 20-30 years have been documented as a rare consequence of sporadic late manifestation [9]. Approximately $40-60 \%$ of symptomatic patients are at risk for the development of melanomas that accordingly worsen the prognosis of these patients. Milder clinical symptoms due to increased brain pressure include headaches, nausea, and dizziness.

\section{Case}

$\nabla$

A 30-year-old GII, PI presented in the $28^{\text {th }}$ gestational week with suspicion of enlargement of the cisterna magna. The family history and the course of the pregnancy to this point were normal. Neurosonography showed a $16 \times 33 \times 23 \mathrm{~mm}$ isolated cyst in the region of the posterior cranial fossa without evidence of additional fetal malformations in the CNS and the other organs. Sonographic diagnosis of a fetal arachnoid cyst ( 0 Figs. 1 ) was confirmed on intrauterine MRI. Additional malformations were also not detected on MRI. Intrauterine sonographic monitoring did not show any progression of the finding or any indication of hydrocephaly or other anomalies of the CNS. The newborn had a giant pigmented nevus with satellitosis ( $\bullet$ Fig. 2 ). The T1-weighted sequences in postnatal MRI of the CNS showed parenchymal melanosis with a typical location in the region of the amygdalae (unilateral), the pons, the thalami, and the frontal lobe (o Figs. 3 ). Due to the typical constellation, the arachnoid cyst was postnatally interpreted as a secondary finding of neurocutaneous melanosis with structural CNS involvement. The development of the child in the present case was normal to the age of 14 months

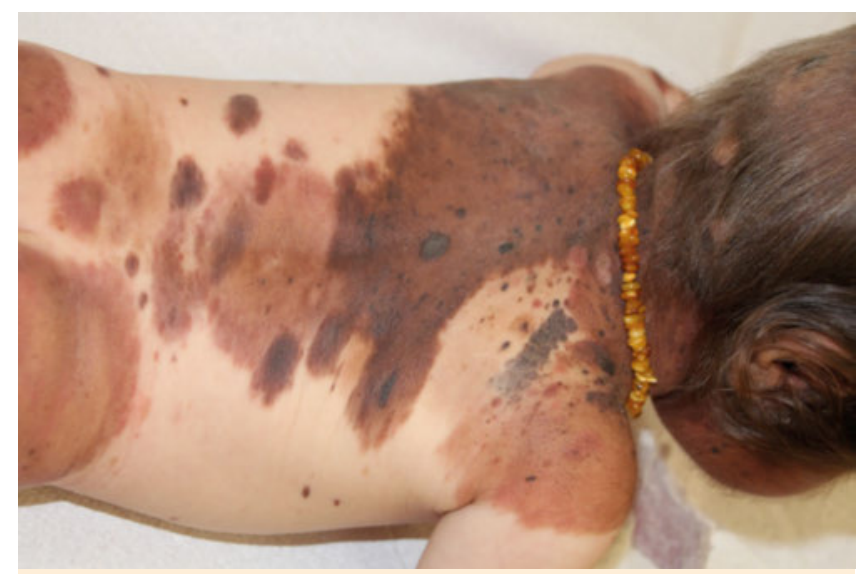

Abb. 2 Neugeborenes weist pigmentiertes Riesennaevus mit Satellitose auf.

Fig. 2 The newborn has a giant pigmented nevus with satellitosis tenen Fällen Fehlbildungen aus dem Formenkreis des DandyWalker Komplexes, Arachnoidalcysten und Patienten mit einer Spina bifida occulta beschrieben [10]. Patienten mit NCM können asymptomatisch oder symptomatisch sein unabhängig vom Fehlen oder Vorhandensein von charakteristischen ZNS-Befunden im MRT. In ca. einem Drittel der Fälle mit NCM kommt es zu symptomatischen Verläufen [9]. In der Regel treten klinische Beschwerden in den ersten 2 Lebensjahren zutage. Die ZNS - Symptome können als Folge einer Infiltration der Leptomeningen, von Melanomen sowie intracerebellären und subarachnoidalen Blutungen oder cervikaler bzw. lumbosacraler Infiltration des Rückenmarks angesehen werden. Zusätzlich besteht ein erhöhtes Risiko für eine Epilepsie, eine Hydrocephalie und für Ataxien. In ca $10 \%$ der Fälle ist mit einer neuromotorischen Retardierung zu rechnen [9]. Eine spinale Melanosis findet sich bei ca. 20\% der betroffenen Kinder. Das Spektrum der Symptome reicht hierbei von Blasen-und Darmentleerungsstörungen bis zur Hemiparese [9]. Als seltene Folge einer sporadischen Spätmanifestation sind vor allem psychiatrische Erkrankungen wie z.B. Depressionen und Psychosen im Alter zwischen 20-30 Jahren dokumentiert [9]. Bei symptomatischen Patienten können sich in ca. 40-60\% der Fälle Melanome entwickeln, die die Prognose entsprechend verschlechtern. Mildere klinische Symptome aufgrund eines erhöhten Hirndrucks sind Kopfschmerzen, Übelkeit und Schwindel.

\section{Case \\ $\checkmark$}

Eine 30 jährige GII, PI wurde in der 28. Schwangerschaftswoche mit V.a. eine Erweiterung der Cisterna magna vorgestellt. Die Familienanamnese und der bisherige Schwangerschaftsverlauf waren unauffällig. Die Neurosonograpfie zeigte im Bereich der hinteren Schädelgrube eine $16 \times 33 \times 23 \mathrm{~mm}$ isolierte Zyste ohne Anhalt für weitere fetale Felbildungen im ZNS und den übrigen Organen. Die sonografische Diagnose einer fetalen Arachnoidalcyste ( $\bullet$ Abb. 1) wurde im intrauterinen MRT bestätigt. Zusätzliche Fehlbildungen konnten auch im MRT nicht festgestellt werden. Der sonografische Verlauf intrauterin zeigte keine Progression des Befundes und keine Hinweise für eine Hydrocephalie oder andere Anomalien des ZNS. Das Neugeborene wies einen pigmentierten Riesennaevus mit Satellitose auf (○ Abb.2). Im postnatalen MRT des ZNS zeigten die T1 gewichteten Sequenzen eine parenchymale Melanose mit typischer Lokalisation im Bereich der Amygdalae beidseits, der Pons, der Thalamie und des Frontallappens ( $\triangle$ Abb.3). Postnatal wurde aufgrund der typischen Konstellation die Arachnoidalcyste als Nebenbefund des Krankheitsbildes eines Neurocutanen Melanosis mit struktureller ZNS-Beteiligung interpretiert. Die Entwicklung des Kindes im vorliegenden Fall war bis zum Alter von 14 Monaten bislang unauffällig mit altersentsprechendem Neurostatus, zeitgerechter Sprachentwicklung, ohne Anfallsleiden oder emotionaler Dysregulation.

\section{Diskussion \\ $\nabla$}

Eine Arachnoidalcyste tritt sehr selten im Rahmen einer anderen Grunderkrankung auf und hat in der Regel eine günstige Prognose. Dementsprechend können Eltern, bei deren Kind eine isolierte Arachnoidalcyste sonografisch diagnostiziert wird, mehrheitlich beruhigt werden. Zur Befundbestätigung erscheint die 


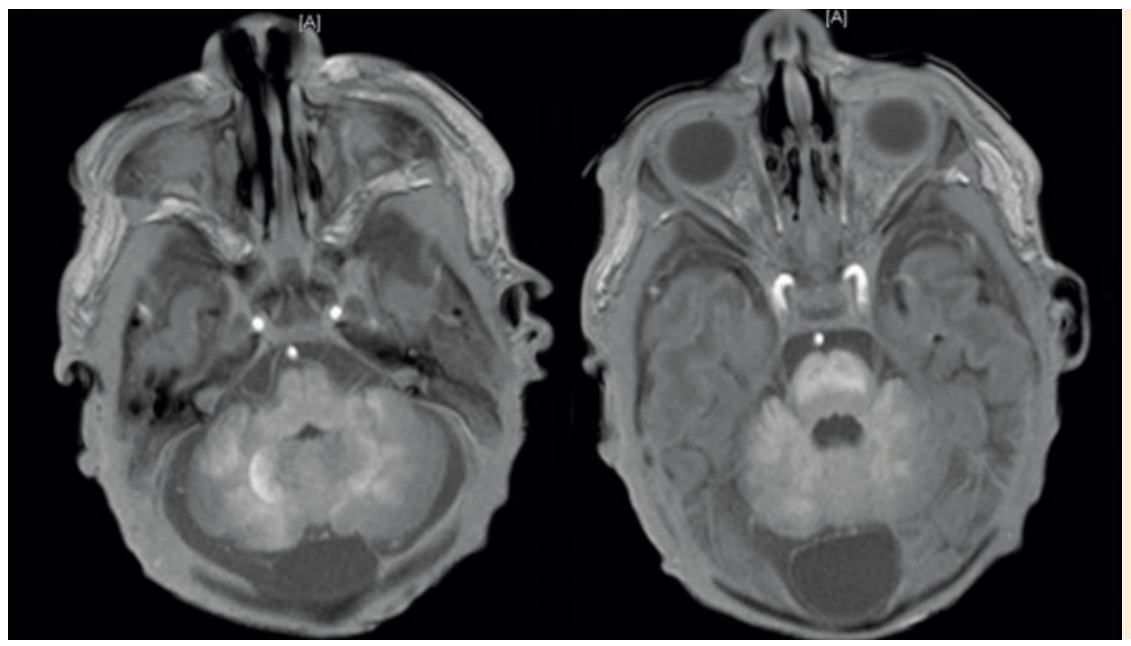

Abb.3 Im postnatalen MRT des ZNS zeigten die T1 gewichteten Sequenzen eine parenchymale Melanose mit typischer Lokalisation im Bereich der Amydalae beidseits, der Pons, der Thalamie und des Frontallappens

with age-appropriate neurological status, proper language development, and no seizure disorders or emotional dysregulation.

\section{Discussion}

\section{$\nabla$}

An arachnoid cyst rarely occurs as part of another primary disease and typically has a favorable prognosis. Most parents whose children have been diagnosed with an isolated arachnoid cyst on ultrasound can therefore be reassured. Prenatal MRI seems appropriate for confirming findings and is increasingly being performed for this purpose. A possible reason for the aggregation of nevus melanocytes of the CNS not being visible on intrauterine MRI in the present case can be due to late manifestation. Children with large congenital melanocytic nevi $(6-9 \mathrm{~cm})$ have a significantly higher risk for neurocutaneous melanosis [7, $9,10]$. Postnatal MRI of the infant's CNS is therefore obligatory even in the case of normal preliminary MRI findings in the fetus. Fetal neurosonography and prenatal MRI should be viewed as complementary methods. However, these methods cannot fully detect all CNS anomalies and other anomalies. Parents must be informed of the low remaining risk even if no other fetal anomalies are detected by both methods. The course of the present case of a child with a giant pigmented nevus in combination with multiple satellites and multifocal melanosis of the CNS indicates a favorable neurological prognosis. The pronounced, large pigmented nevi require monitoring with respect to an increased risk for melanoma. In the case of nevi covering a large area and giant pigmented nevi with multiple satellites, the risk for melanoma correlates with the size of the lesion and is approximately $4-15 \%$ [8]. There is a lack of consensus in the literature regarding the cosmetic consequences and treatment options. Cases are treated on an individual basis. In the case of smaller and medium-sized nevi, there is a relative treatment indication, while in the case of very large nevi, the medical indication for melanoma prophylaxis must be discussed since melanomas can also occur in CNS lesions, albeit rarely. It must also be considered that excision may be difficult in the case of nevi covering a large area and may result in excessive scarring $[8,11,12]$. NCML can be caused by somatic mutations in the genes NRAS and BRAF. Therefore, most cases are a sporadic occurrence. Rare familial forms can be explained by germ cell mosaicism [13].
Durchführung des pränatalen MRT angemessen und ist zunehmend weitverbreitet. Mögliche Gründe dafür, dass im vorliegenden Fall die Aggregation von Naevus-Melanozyten des ZNS im intrauterinen MRT nicht zu sehen waren, können durch eine späte Manifestation bedingt sein. Kinder mit großen kongenitalen melanozytären Naevi $(6-9 \mathrm{~cm})$ weisen ein signifikant höheres Risiko für eine neurokutane Melanose auf [7, 9, 10]. Dementsprechend ist ein postnatales MRT des kindlichen ZNS obligat, auch bei unauffälligem fetalen Vorbefund im MRT. Insgesamt zeigt sich, dass die fetale Neurosonografie und das pränatale MRT als ergänzende Methoden anzusehen sind, jedoch nicht alle ZNS oder andere Anomalien vollständig erfassen können. Eltern sind auf seltene Restrisiken hinzuweisen, auch wenn in beiden Verfahren keine weiteren fetalen Anomalien festgestellt werden. Der vorliegende Fall eines Kindes mit pigmentiertem Riesennävus in Kombination mit multiplen Satelliten und multifokaler Melanosis des ZNS deutet im bisherigen Verlauf auf eine günstige neurologische Prognose hin. Die ausgeprägten grossflächigen Pigmentnävi sind im Hinblick auf ein erhöhtes Risiko für Melanome kontrollbedürftig. Bei grossflächigen Befunden und pigmentierten Riesennävi mit multiplen Satelliten korreliert das Risiko für ein Melanom mit dem Ausmass der Läsion und liegt bei ca. 4-15\% [8]. Die kosmetischen Folgen und Behandlungsoptionen werden in der Literatur unterschiedlich diskutiert und individuell behandelt. Bei kleineren und mittelgroßen Nävi besteht eine relative Behandlungsindikation, wohingegen bei sehr grossen Befunden die medizinische Indikation zur Melanomprophylaxe zu diskutieren ist, da selten Melanome auch in den ZNS Läsionen entstehen können. Bedacht werden muss auch, dass bei grossflächiger Ausdehnung eine Exzision u.U. erschwert sein und zu einer exzessive Narbenbildung führen kann $[8,11,12]$. Ursachen der NCML sind somatische Mutationen in den Genen NRAS und BRAF. Die allermeisten Fälle sind demzufolge sporadisch, seltene familiäre Formen können durch einen Keimzellmosaizismus erklärt werden [13].

\section{Tercanli S, Itin P, Weber P, Basel}

\section{References}

1 Karl K, Kainer F, Heling K-S, Chaoui R. Fetale Neurosonografie: die erweiterte Untersuchung des ZNS beim Fetus. Ultraschall in Med 2011; 32: 342-361

2 Denise Pugash, Martin Krssak, Vanessa Kulemann, Daniela Prayer. Magnetic resonance spectroscopy of the fetal brain. Prenat Diagn 2009; 29: $434-441$ 
3 Pugash D, Brugger PC, Bettelheim D, Prayer D. Prenatal ultrasound and fetal MRI: The comparative value of each modality in prenatal diagnosis. Eur J Radiol. 2008 Nov; 68(2): 214-26.

4 BlaicherW, Prayer D, Mittermayer C, Weninger M, Birnbacher R, Deutinger J, Bernaschek G. The Clinical Impact of Magnetic Resonance Imaging in Fetuses with Central Nervous System Anomalies on Ultrasound Scan. Ultraschall in Med 2005; 26(1): 29-35

5 De Keersmaecker B, Ramaekers P, Claus F; Witters I, Ortibus E, Naulaers $G$, Van Calenbergh F, De Catte L. Outcome of 12 antenatally diagnosed fetal arachnoid cysts: Case series and review of the literature: European Journal of Paediatric Neurology, Volume 19, Issue 2, March 2015, Pages 114-121

6 Kadonaga JN, Frieden IJ. (1991) Neurocutaneous melanosis: Definition and review of the literature. J Am Acad Dermatol 24: 747-755

7 Frieden IJ, Williams ML, Barkovich AJ. Giant congenital melanocytic nevi: brain magnetic resonance findings in neurologically asymptomatic children. J Am Acad Dermatol (1994) 31: 423-429

8 Krengel S. Kongenitale melanozytäre Nävi CME Dermatol 2008; 3(2): 106-122
9 Makkar HS, Frieden IJ. Neurocutaneous melanosis. Semin Cutan Med Surg. 2004 Jun; 23(2): 138-44

10 Acosta FL, Binder DK, Barkovich AJ, Frieden IJ, Gupta, N. Neurocutaneous melanosis presenting with hydrocephalus Case report and review of the literature. J Neurosurg (Pediatrics 1) 102: 96-100, 2005

$11 \mathrm{Hamm} \mathrm{H}$. Kongenitale melanozytäre Nävi: aktuelle Behandlungsempfehlungen. In: Plewig G, Thomas P (Hrsg). Fortschritte der praktischen Dermatologie und Venerologie 2006. Band 20. Heidelberg: Springer 2007; 277-81.

12 Schiestl C. The challenge of two layers. Das Zürcher Behandlungsmodell. Kongress Denkmal Muttermal, Zürich, 18.-19. 05. 2006. http:// www.denkmal-muttermal.ch

13 Charbel C, Fontaine, RH, Malouf GG, Picard A, Kadlub N, El-Murr N, HowKit A, Su X, Coulomb-L'Hermine A, Tost J, Mourah S, Aractingi S, Gue 'gan $S$. NRAS Mutation Is the Sole Recurrent Somatic Mutation in Large Congenital Melanocytic Nevi. Journal of Investigative Dermatology advance online publication, 14 November 2013 